\title{
PERCEIVING THE IMPACT OF BROWNFIELDS ON THE REAL ESTATE PRICES: A CASE STUDY FROM FOUR LOCATIONS IN THE CZECH REPUBLIC
}

\author{
Kamila TURECKOVA ${ }^{1}$, Jan NEVIMA ${ }^{1}$
}

DOI: 10.21163/GT_2018.132.11

\begin{abstract}
:
The abandoned buildings and areas - brownfields are continuously an integral part of settlements across Europe. One form of interaction between brownfields and the surrounding area is through the property market when it is clear that brownfields affect the value of real estate in its neighborhood. The subject of our research was why and with what intensity this is happening. The research was conducted between 2017 and 2018 in four municipalities in the Czech Republic (Olomouc, Skrbeň, Stonava and Životice) through a questionnaire survey aimed at identifying factors that determine the specific perception of the impact of brownfields on the value of surrounding real properties. The results of the research clearly supported the logical assumption that brownfields are perceived completely negatively in the context of their existence and the impact of their presence on the surrounding residential property values of the inhabitants of the selected municipalities. The findings are a desirable public interest argument for finding solutions to brownfield issues. It is necessary to suppress the negative side of brownfields and transform it into the potential for further development of the area and regions.
\end{abstract}

Key-words: Brownfield, Residential property values, Real estate price, Czech Republic.

\section{INTRODUCTION}

Brownfields, abandoned and unused areas and objects, are an integral part of the urban consequences of human activity, which can transform into a source of untapped potential for development in both the regional and transnational spheres (Turečková et al., 2018). The increasing dynamics of socio-economic change is continually accompanied by the transformation of residential and living space, where inappropriate areas are left "to their fate" so that some of them may find new, alternative uses in the future. While the empty brownfield is characterized by a number of negative externalities, the effects of positive externalities are reflected in the process of its regeneration, increasing the social surplus not only resulting from the restoration of public space but also from the environmental responsibility and cultural link of our ancestors (Navrátil et al, 2018). Brownfields are perceived as significant, albeit specific, elements of territorial development and spatial arrangement of the cultural and natural environment (Brown, 2012 or Krzysztofik et al., 2016). Within the framework of the modern (modern) approach and in the context of economic development and the simultaneous dynamic deepening of the quality of life. The new use of temporarily abandoned areas and areas helps to reduce the pressure on construction on greenfields in the urbanized area and maintain the compactness of the current built-up area (Sucháček, 2013). The argument of the undesirable effects associated

\footnotetext{
${ }^{1}$ Silesian University in Opava, Department of Economics and Public Administration, 73340

Karvina, Czech Republic; tureckova@opf.slu.cz, nevima@opf.slu.cz
} 
with suburbanization and urban sprawl also speaks for the reuse of abandoned areas (Frantal et al., 2015, Putman, 2000, Oliver 2001, Jackson, 2002 or Sýkora, 2003).

Indeed, boosting support for brownfield regeneration might contribute to more sustainable development of cities and rural municipalities from the perspective of their physical compactness (Kladivo and Halas, 2012), might reduce consequent environmental and health risks (Litt et al., 2002, Eiser et al., 2007) for local population and significantly contribute to an increase of attractiveness of cities and municipalities (Andrés and Grésillon, 2013 or Somlyódyné Pfeil, 2017). Such support might also help to enhance our responsibility (Morvay, 2017) for implications of our industrial history and business activities (Pakšiová, 2016) that is still significantly affecting face and structure of our contemporary cities, countries and Europe Union. Generally, support for brownfields regeneration might strengthen our nowadays more environmentally friendly path of thinking about urban space that prefers utilization of existing properties over those that are being built on greenfields (De Sousa, 2003). Therefore, due to the importance for wider development, this branch is also subject of the EU financial support (Melecký and Staníčková, 2017).

The content of this paper is to analyze one of the unwanted speeches that brownfields in the built-up area are related to, and their property to influence the value of the real estate that is adjacent to the brownfield. This area of research is addressed in terms of perception of the local population of four municipalities in the Czech Republic where the research was carried out. This research builds on earlier primary research in three other cities of the Czech Republic, and further specifies the subject (see Turečková et al., 2017a, Turečková et al., 2017b, Škrabal et al., 2017 and Chmielová et al., 2017). Based on the logical assumption that brownfields are perceived negatively in the context of their impact on the value of the (residential) immovable property, which is undesirably transformed into the reduced price at which these properties are traded on the market (e.g. Bowes and Ihlanfeldt, 2001). Through this lower property price, there is a social loss from the economic point of view and the social surplus decreases. By identifying the undesirable factors associated with brownfields, it is possible to define the possibility of mitigating their negative impact on the prices of surrounding properties and to better activate remedial measures (Turečková, 2018). The aim of the paper is to examine the influence of brownfields on the residential property values that are located in their neighbourhoods, as perceived by the local population.

It can be assumed that proximity of neglected, abandoned and decaying grounds impacts values of residential properties. Reasons behind this hypothesis lie for example in the lower level of aesthetic quality that is usually connected to such abandoned or neglected brownfields. Next reason could be linked to possible contamination of these sites, their bad technical state or occurrence and concentration of socio-pathological phenomena in these buildings (like homelessness, high level of criminality etc.).

Our results and findings are based on primary research conducted between 2017 and 2018 through a questionnaire survey in four villages in Moravia, Czech Republic. Municipalities Stonava and Životice are located in the Moravian-Silesian Region and the city Olomouc and village Skrbeň in the Olomouc Region. It is to be expected that differences in the location of municipalities will be reflected in respondents' answers. Because while Stonava and Životice are located in the Ostrava-Karvina agglomeration, typical of the huge occurrence of brownfields after heavy industry and mining, Olomouc 
and Skrbeň are located in the agricultural area of Haná. The number of respondents was 352.

\section{THEORETICAL FRAMEWORK OF THE STUDY}

It is not possible to define a brownfield uniformly because its explanation depends on the time, geographical, political, economic and social perception of the given concept (Turečková, 2018). In general, we can characterize the brownfield in the widest possible sense as an abandoned area (an object, building, area, land) that previously performed a certain economic activity but which has already been terminated and new use has not been found for this area (Martinát et al., 2017). With reference to former economic activity in a given brownfield, we are divided into brownfields for industrial, mining, military, transport, agricultural and brownfields for former amenities (shopping centers, hospitals, restaurants, apartment buildings, etc.) (Martinát and Turečková, 2016). Brownfields can also be ecologically polluted, contaminated and dangerous from a technical construction point of view. Because these sites are decaying (even decades), they disrupt the urban structure and architectural style of the site, are unsightly, and are the usual place of concentration of socially pathological phenomena (especially homeless and drug addicts). Within the European Union, brownfields are defined by the Organization for Economic Cooperation and Development (2017), which defines brownfields as a land and property located inside urbanized areas that have lost their function and use and are likely to contain environmental burdens. The National Brownfield Regeneration Strategy of the Czech Republic (CzechInvest, 2008) or previously Alker (2000) or Yount (2003) define brownfield as the real estate property (land, building or ground) that is insufficiently utilized, neglected and might be also contaminated. The occurrence of brownfields is usually perceived as a weakness or a threat for future development of cities, towns and municipalities. On the other, brownfields might also be considered as an opportunity for development (Adams et al., 2010). These sites are usually unsightly and aesthetically do not meet requirements of the local population how the city should look like which significantly affect the perception of these sites (Martinat et al., 2017). The problem of brownfields is especially distinct in cities that are heavily affected by the recent decay of the heavy industry and mining, where it might be assumed that brownfields are specifically perceived (Krzysztofik et al., 2012). Systematic regeneration of brownfields might undoubtedly contribute to the improvement of the quality of life in these cities (Pediaditi et al., 2010) and at least partially contribute to a more environmentally friendlier way of thinking of nowadays society (Apsan, 2002).

The occurrence of brownfields significantly affects values of residential properties that are located in neighbourhoods of these sites (e.g. De Sousa, 2000, Kaufman and Cloutier, 2006, Mihaescu and vom Hofe, 2012, Sun and Jones, 2013) and has significant fiscal consequences (Růžičková and MacGregor Pelikánová, 2014, Jánošíková and MacGregor Pelikánová, 2017). It is also well known that the property prices are constructed by characteristics of the local real estate market where geographical location belongs to factors of crucial importance (e.g. Can, 1992 or Hesse, 2004). Undoubtedly, values of residential properties in the neighbourhood of brownfields are also considerably influenced by the way how population perceive these sites (Munroe, 2007). Willingness to purchase the real estate in the proximity of brownfield is affected by the mix of factors, part of them might be described as "hard" factors (like already mentioned geographical location, accessibility of the site, availability of infrastructure) and part of them as "soft" factors where perception 
surely belongs. These soft factors are usually not of static, but more of dynamic nature that might be changed due to course of time as the process of particular brownfield regeneration approaches. On the contrary, once brownfield regeneration process is finished, values of residential properties in neighbourhoods usually increase.

\section{METHODOLOGY AND DATA}

The primary research involved on perceiving the influence of brownfields on the value of nearby properties and its real estate prices. As was mention these present results are the next in a series of extensive research on the territory of Morava (the part of territory of the Czech Republic). Individual phases of conducted research were performed simultaneously in one city (Olomouc) and tree rural municipality (Skrbeň, Stonava, Životice) of the Moravian-Silesian Region and The Olomouc region in 2017 and 2018 (see Figure 1). The primary research was relies on questionnaire survey and its aim was to ascertain opinions and attitudes of the local population on the issue of the influence of brownfields on prices of the neighbouring real estate.

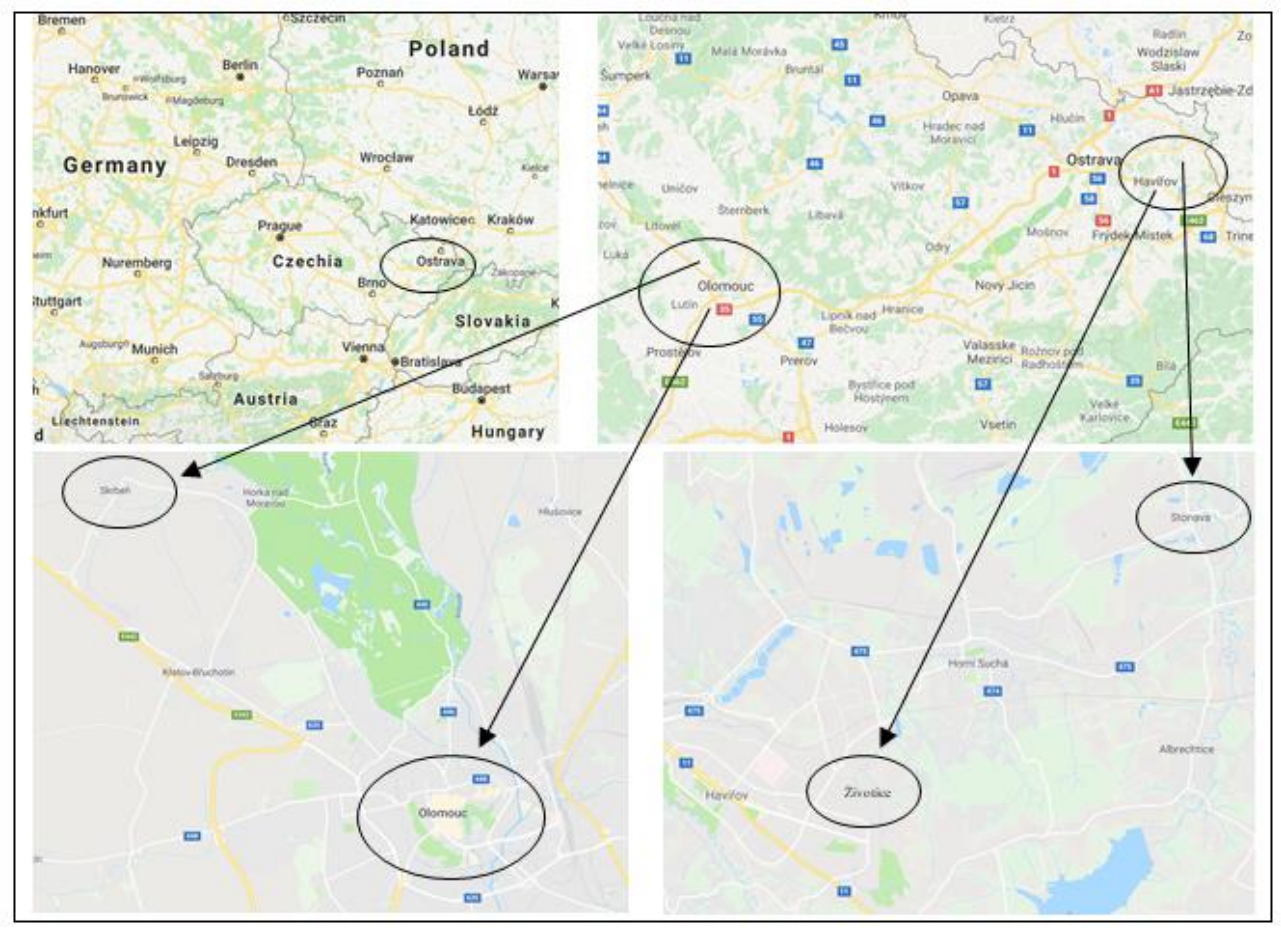

Fig. 1 Location of the four case study municipalities

Source: Google Maps, authors processing

Firstly, was to determine the number of brownfields and describe its characteristics in selected municipalities by the observation method. On the basis of open access brownfields inventories (CzechInvest and Invest More) and own research, a database for the four municipalities was developed. For the purposes of this paper there was necessary the 
information about number of brownfields and its expanse (area). In Olomouc was determined 14 brownfields, in Skrbeň 4, in Stonava 11 and in Životice 6 brownfields. This information is important in context of respondents' views on the influence of brownfields on the price of surrounding properties. It can be assumed that the more respondents have direct experience with brownfields, the more negative they will perceive,

Secondly, the data on perception of residential property values were gathered by means of the questionnaire survey. The questionnaire has been created on the basis of previous studies and contained 12 questions. A preliminary survey was conducted in March 2016 to be sure that individual questions are clearly defined and to avoid any misinterpretations. Individual questionnaires were gathered by trained university students by a face-to-face communication with respondents. The questionnaires were completed by the method of semi-structured interviews. Last year we had 347 respondents from tree municipalities: Karviná, Orlová and Dětmarovice (see Turečková et al., 2017) and in this year a number of respondents that participated in the research were 352 in total (120 respondents from Olomouc, 80 respondents from Skrbeň, 50 respondents from Stonava and 102 respondents from Životice). A number of respondents, who participated in the survey, were ensured to be at least $3.4 \%$ of the total population of individual municipalities. All respondents lived in selected municipalities and their socioeconomic, demographic, educational and gender structure of the population was balanced (please see Table $\mathbf{1}$ for the structure of respondents). Factors behind were also determined to ensure why and how the occurrence of brownfields affects the value of local residential properties. Respondents were selected to be sure that all parts of municipalities, where brownfields are located, are represented.

Segmentation of respondents of surveys in four municipalities.

Table 1

\begin{tabular}{|l|l|c|c|c|c|}
\hline \multirow{3}{*}{ Variables } & Municipality & Olomouc & Skrbeñ & Stonava & Životice \\
\cline { 2 - 6 } & Population (year) & $99809(2015)$ & $1206(2012)$ & $1828(2012)$ & $1322(2017)$ \\
\cline { 2 - 6 } Gender & Number of questionnaires & $\mathbf{1 2 0}$ & $\mathbf{8 0}$ & $\mathbf{5 0}$ & $\mathbf{1 0 2}$ \\
\hline \multirow{5}{*}{ Age } & Female & $59 \%$ & $56 \%$ & $56 \%$ & $61 \%$ \\
& Male & $41 \%$ & $44 \%$ & $44 \%$ & $39 \%$ \\
\hline \multirow{5}{*}{ Education } & $18-25$ years & $32 \%$ & $50 \%$ & $8 \%$ & $6 \%$ \\
& $26-45$ years & $39 \%$ & $31 \%$ & $38 \%$ & $56 \%$ \\
& $46-65$ years & $21 \%$ & $19 \%$ & $34 \%$ & $25 \%$ \\
& 65 and more years & $8 \%$ & $0 \%$ & $20 \%$ & $13 \%$ \\
\hline \multirow{5}{*}{ Social statury } & Elementary & $12 \%$ & $6 \%$ & $6 \%$ & $11 \%$ \\
& Secondary without final exam & $35 \%$ & $17 \%$ & $38 \%$ & $28 \%$ \\
& Secondary with final exam & $29 \%$ & $63 \%$ & $46 \%$ & $37 \%$ \\
& Higher professional education & $8 \%$ & $6 \%$ & $4 \%$ & $9 \%$ \\
& Tertiary & $16 \%$ & $8 \%$ & $6 \%$ & $15 \%$ \\
\hline & Employees & $43 \%$ & $50 \%$ & $48 \%$ & $25 \%$ \\
& Students & $26 \%$ & $31 \%$ & $8 \%$ & $20 \%$ \\
& Entrepreneurs & $4 \%$ & $0 \%$ & $6 \%$ & $24 \%$ \\
& Unemployed & $4 \%$ & $0 \%$ & $0 \%$ & $9 \%$ \\
& Retired persons & $9 \%$ & $0 \%$ & $30 \%$ & $15 \%$ \\
& On maternal/parental leave & $14 \%$ & $19 \%$ & $8 \%$ & $8 \%$ \\
\hline \multirow{5}{*}{ Habitation } & Own residential house & $25 \%$ & $67 \%$ & $54 \%$ & $66 \%$ \\
& House in rent & $3 \%$ & $0 \%$ & $0 \%$ & $34 \%$ \\
& Dormitory & $8 \%$ & $0 \%$ & $0 \%$ & $0 \%$ \\
\cline { 2 - 6 } & Own apartment/flat & $34 \%$ & $28 \%$ & $0 \%$ & $0 \%$ \\
& Cooperative apartment & $0 \%$ & $0 \%$ & $0 \%$ & $0 \%$ \\
& Apartment in rent & $30 \%$ & $5 \%$ & $46 \%$ & $0 \%$ \\
\hline
\end{tabular}


Table 2 shows selected indicators of municipalities and brownfields on its territory. For purpose of our research was useful to set by authors the index named index of civic proximity to brownfield which is calculated as:

index of civic proximity to brownfield $=\frac{\text { share of areas of brownfields on area of municipality }}{\text { area of municipality per capita }}$

The value of index is within the range $(0, \infty)$ and the smaller value of index is better because means, in generally, less experience of inhabitances of municipalities with the brownfields from a spatial point of view. The higher value of this index constitutes that the inhabitants of a given village or city live closer to brownfields than lower value. If is the value of index of civic proximity to brownfield is zero it means no brownfields on the territory of the municipality. This information given via created index will be connected with the results of questionnaire survey in the next part of this paper.

Table 2.

Selected indicators of municipalities and brownfields

\begin{tabular}{|r|c|c|c|c|}
\hline Indicator/Municipality & Olomouc & Skrbeň & Stonava & Životice \\
\hline Area of municipality (ha) & 10336 & 787 & 1387 & 430 \\
\hline Number of brownfields & 14 & 4 & 11 & 6 \\
\hline Area of brownfields (ha) & 55 & 0.584 & 115 & 0.71 \\
\hline Share of area of brownfields on area of municipality & $0.53 \%$ & $0.07 \%$ & $8.30 \%$ & $0.17 \%$ \\
\hline Population & 99809 & 1206 & 1828 & 1322 \\
\hline Area of municipality per capita (ha) & 0.10 & 0.65 & 0.76 & 0.33 \\
\hline Index of civic proximity to brownfield & 0.05 & 0.00 & 0.11 & 0.01 \\
\hline Order by index & 3 & 1 & 4 & 2 \\
\hline
\end{tabular}

Sources: set of own surveys and Czech Statistical Office Note: the smaller index value is better

As we can see from the Table 2 through comparting the value of index of civic proximity to brownfield and also with other values of selected indicators present in table there is clear that, in general, the largest personal experience with brownfields should have the inhabitants of Stonava. Eleven brownfields in Stonava have the largest share of size of area of brownfields on size of area of municipality (8.30\%). This factor is very strong even in fact that the area of municipality per capita is the smallest ( 0.76 hectare per capita). On the other hand, village Skrbeň in the Olomouc Region has only 4 brownfields with very small size of their area and relatively large area of municipality per capita $(0.65)$ what indicated assumption that inhabitants from Skrbeň should have the lowest direct experience with brownfields in spatial and residential point of view. Whether these findings correspond to the findings of the primary research are set out in the next chapter 4 called Results perceiving the impact of brownfields on the real estate prices. 


\section{RESULTS - PERCEIVING THE IMPACT OF BROWNFIELDS ON THE REAL ESTATE PRICES}

The key finding of our survey is (what was also expected base on previous research) that the living in the neighborhood of brownfields is problematic for the majority of respondents (see Figure 2). Quite surprising is the result from municipality Životice where only $6 \%$ of respondents do not mind living near brownfields while in other 3 municipalities it is between $26 \%-33 \%$. It could be assumed that local population is more used to live in the neighborhoods of these sites than in Životice.

This result and differences among individual municipalities can be explained rather a consequence of negative phenomena that are usually connected to the occurrence of brownfields (criminality, homelessness etc.) and, especially in case of Životice, it could be the fact that it is a small village with a higher population density ( 0.33 ha per capita) in combination with character of its 6 brownfields. Brownfields in Životice are made up of a ruin of a local castle and skeletons of agricultural areas, all of them are located in the center of the village and therefore in the eyes of the inhabitants of the village.



Fig. 2. Unwillingness to live in the neighbourhood of brownfields. Source: own survey $(n=352)$

Much more impressive differences in opinions of respondents were found in a question, how the local residential property values are affected by the occurrence of brownfields? While the opinions of the respondents from Olomouc and Skrbeň are not very different, the answers of the respondents from Stonava and Životice are more peculiar (see Figure 3). The respondents of these two villages do not admit any influence of brownfields on the prices of surrounding properties on the one hand but on the other hand about $48 \%$ of respondents stated that due to the occurrence of brownfields the residential property values are lower between $20 \%-40 \%$ and $14 \%$ of respondents of Stonava and $46 \%$ of respondent of Životice (...) are lower by $50 \%$ in comparison to other parts of the city without brownfields.

Overall, for more than three quarters of respondents, the existence of brownfields has some (smaller or larger) impact on the value of residential properties. This result could be supported by other responses (results are presented in Figure 4 and 5). In the next step, we asked the respondents if they would buy a residential property in the neighbourhoods of brownfield if its price was about $20 \%$ lower than the usual price. It seems that our hypothesis related to the specific perception of brownfields in Stonava and Životice are confirmed as the population of these two municipalities again evaluates this problem again 
differently (with much higher polarity) in comparison to other two cases (Olomouc and Skrbeň). We assume that this might be caused by the dense occurrence of brownfields in Stonava and Životice and significant everyday experiences of the local population with life with brownfields and consequent occurrence of socially problematic phenomena.

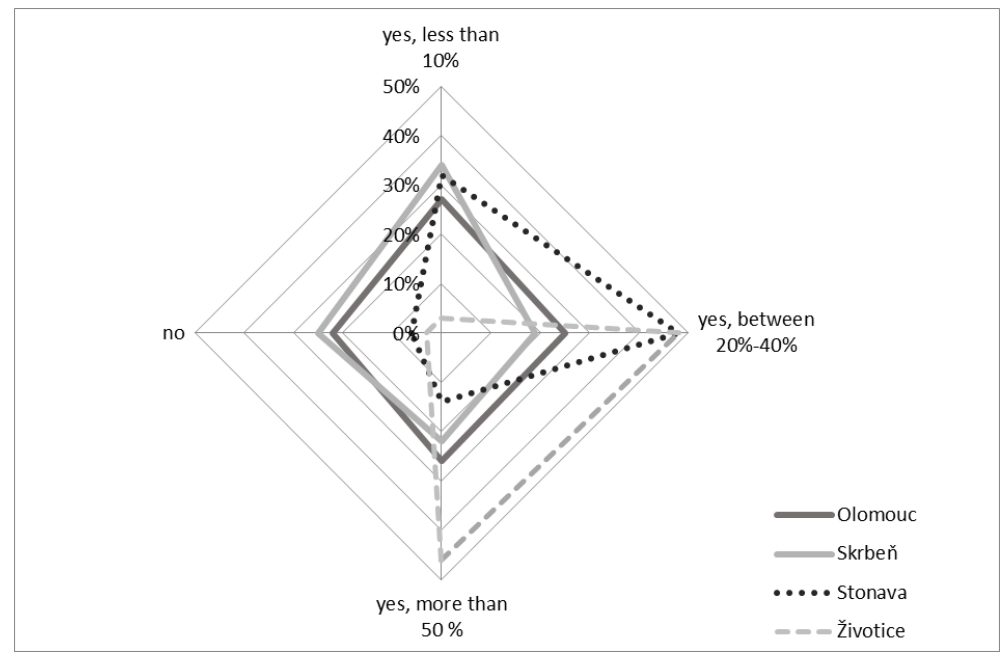

Fig. 3 Influence of brownfields on residential property values in four municipalities.

Source: own survey $(n=352)$

When we asked respondents to evaluate their willingness to buy the residential property in immediate proximity of brownfield if the price is lower by $20 \%$ the response were significantly negative replies among respondents from Životice and Stonava where only $5 \%$, respectively $14 \%$, of them were open to buy such residential property (see Figure 4). Respondents from Skrbeň and Olomouc were not so negative in their answers and more than $56 \%$, respectively $45 \%$, of them would be opened to buy such real estate without any problems.

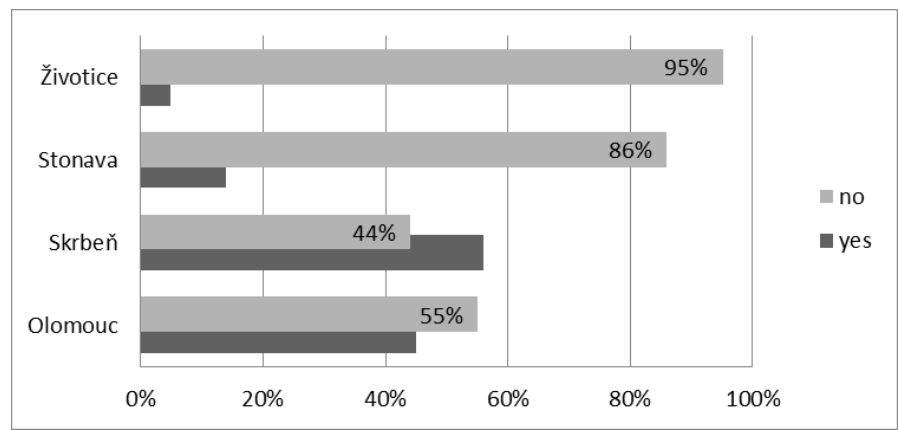

Fig. 4. Willingness to buy residential property in immediate proximity of brownfield if price is lower by $20 \%$.

Source: own survey $(n=352)$ 
Part of the research was also to determine the factors that people brownfields perceive negatively and which affect opinions of respondents that brownfields significantly affect the value of residential properties in their neighbourhoods. The reasons why brownfields are undesirable are as follows: (1) the brownfield is usually dangerous from a construction and technical point of view, (2) there is no certain future use of brownfield, (3) brownfield is aesthetically unsightly, (4) brownfield is dangerous due to possible contamination and pollution that threatens health, (5) brownfield blocks development of the city, and (6) social-pathological phenomena are concentrated in the brownfield.

Respondents could select out of these six defined answers. Shares of positive and negative answers are graphically displayed in Figure 5. Generally, it was found that respondents of all municipalities connect occurrence of brownfields much more strongly to negative consequences because of social-pathological phenomena (like homelessness, criminality, possible contamination and health risks for population etc.). The second and third major reasons for negative attitudes towards brownfields are dangerous outgoing from a construction and technical state of brownfields and dangerous due to possible contamination and pollution that threatens health. What was surprising was that usually reduced aesthetics of non-regenerated brownfields was not taken into account as a serious problem, similarly as consequences for urban planning (brownfields block development of the city, there is no certain future use of brownfields).

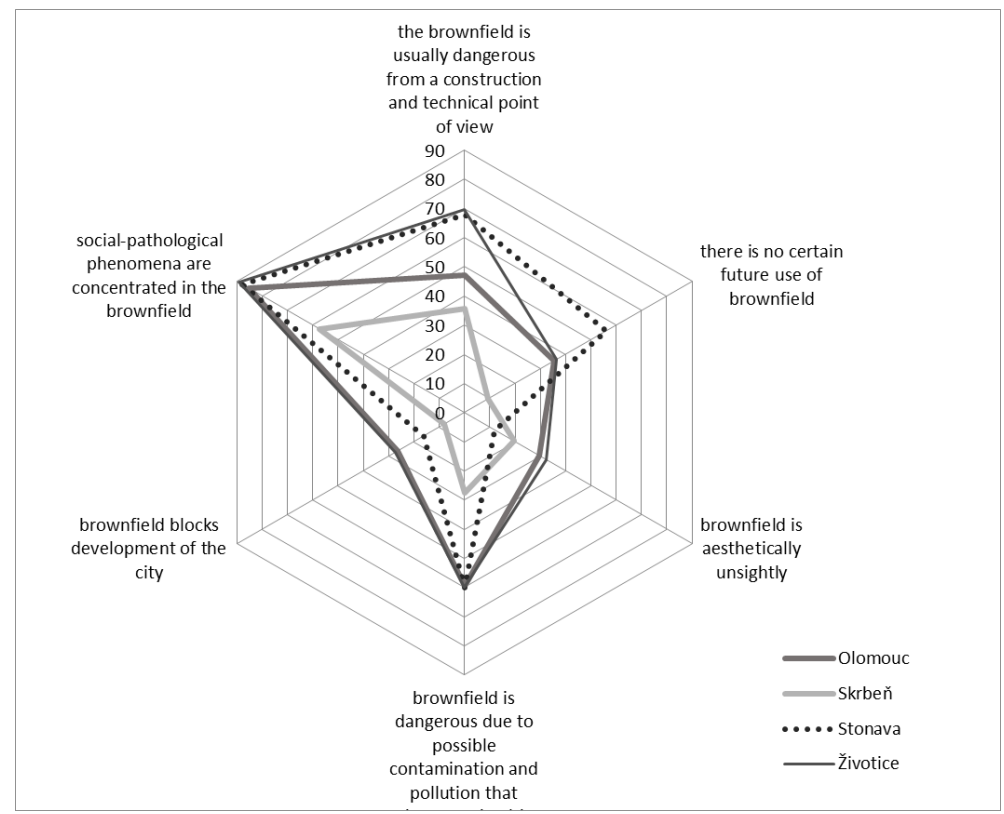

Fig. 5. Reasons why brownfields have significant influence on the residential property values.

Source: own survey $(n=352)$

The largest share of respondents (on average 86\%) is convinced that brownfields as an abandoned sites are problematic and rather dangerous which is the fact that reduces prices of the neighbouring real estate. Main reasons for such argument were identified in the 
concentration of socially pathological phenomena in brownfields (like homelessness, higher rates of criminality, drug dealing, vandalism etc.) (chosen at $80 \%$ ). The second factor that was found as important (around $55 \%$ ) were technical state of brownfields. Respondents were expressing their fears that brownfields are dangerous as for the bad quality of their technical infrastructure, and not usually secured against the intrusion of people who should not be there. They perceive that risks connected to bad statics and neglected maintenance of individual buildings, or failures of concrete structures due to corrosion of materials are very high. The environmental and health risks (occurrence contamination of soils and pollution) that might affect the health of the population that is living in the neighbourhoods was identified as a third important factor (around 52\%). This factor might be interpreted as some kind of distrust that majority of contamination have been removed or cleaned up. The population was quite unsure that these contaminants are safe and do not bear any health risks. Reasons why brownfields negatively influence the price of the neighbouring real estate are for $34 \%$ of respondents connected to uncertainty concerning future use of the site. They usually argued that it is not sure what will be built on a particular brownfield in future and how the site will be used. The $23 \%$ of respondents believes that lower real estate prices of buildings in proximity to brownfields are connected to aesthetics of brownfields. These sites are usually abandoned and neglected, sometimes aesthetically unsightly with peeled façade or are ruined, covered by weed or walls are damaged by graffiti etc. Only $19.5 \%$ of respondents perceived brownfields as barriers for the further development of the city. We can say respondents were not so optimistic when thinking about the future development of their city. It seems that this distrust towards future reduces demand for housing within the city and indirectly it noticeably reduces the value of the local real estate.

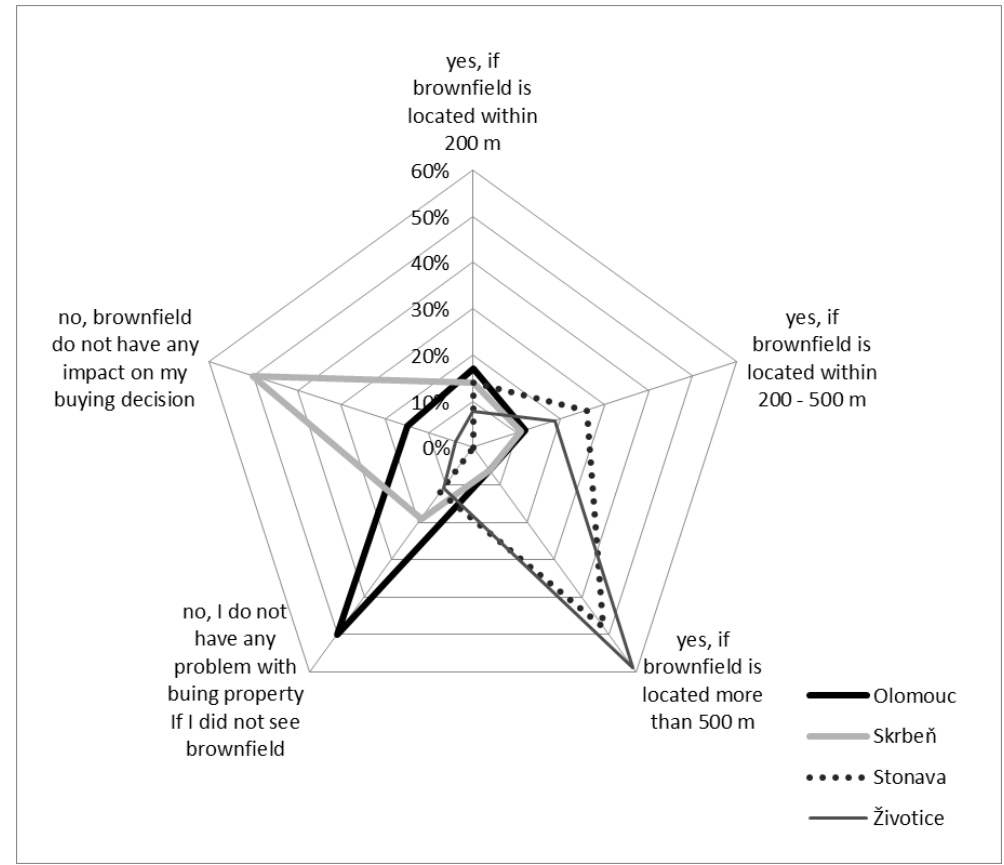

Fig. 6. Influence of brownfields on real estate buying behaviour of respondents. Source: own survey $(n=352)$ 
The last presented research results are answers to the question where respondents were asked to evaluate the possibility to buy the real estate in the proximity of brownfields (see Figure 6). The answers to this question confirm previous findings. While the citizens (in $50 \%-60 \%$ ) of Stonava and Životice would consider buying a property if it was more than 500 meters away from brownfields, the respondents from Olomouc in $40 \%$ do not have any problem with buing property in neighborhood of brownfields if they do not see them. This should be given in matter of fact that the Olomouc is quite big city with a different approach to housing than in the village. What was suprising, for respondents from Skrbeň (in 50\%) brownfields do not play a role in influence their decision to buy real estate or (in $19 \%$ ) if they did not see brownfield. This could be explained via low negative experience with brownfields (see Table 2).

\section{CONCLUSIONS}

Brownfields, the reasons for their origin, the effects of their existence, the problems associated with them and the proposals for their solution are the current topic for professional and lay discussion across public and private bodies and institutions involved in this issue. In the context of the existence of brownfields, it is a priority to find their new, beneficial use. This enables the brownfield to see the potential for further development of the region, together with its regeneration, the growth of economic and social activity and the increased attractiveness of the area for all stakeholders. Leaving abandoned areas without the effort to find alternative uses for them, regional development is hampered by the fact that it prevents the development of the built-up area, adversely affects the environment and society and has an adverse impact on the entire territorial unit.

The aim of the paper was to examine the perception of brownfields on the values of residential properties, as perceived by the local population. The set of semi-structured interviews has been conducted in four municipalities (Stonava, Životice, Skrbeň and Olomouc) that are significantly affected by the occurrence of brownfields. By means of our survey hypothesis was confirmed that the occurrence of brownfields significantly affects the value of the residential properties. Brownfields are perceived quite negatively as the local population believes that they reduce prices of residential properties. This finding is in line with the results of previous studies (e.g. Bond et al., 2004). Respondents of our survey also claimed in their majority that they would not buy the real estate in the proximity of brownfield even if the price was reduced by on fifth in comparison with other locations within the same city or municipality. Such exact finding can be hardly generalized, however, the stand-off of local population from purchasing the real estate in the neighbourhoods of non-regenerated brownfield seems to be clear. This argument might utilized while arguing for the speeding-up of the brownfield regeneration process.

Factors that the most significantly influence such decision is a concentration of socially pathological phenomena, dangerous due to possible contamination and pollution that threatens health and risks connected to possible contamination of brownfields and health risks for the local population. This confirms the expectation that the inhabitants of Stonava and Životice, who comes from the area affected long-term coal mining industry and will be loaded towards brownfields negatively tuned than residents of rural areas Olomouc and Skrbeň, where attitudes to brownfields are not so pronounced and associated with unwanted prejudices. 


\section{ACKNOWLEDGMENT}

This paper was kindly supported by the project with the title; Brownfields in urban and rural space: geographic, economic, historical, legal contexts and their importance for regional development (BURAN) (SGS/21/2016).

\section{R E F E R E N C E S}

Adams, D., De Sousa, C., \& Tiesdell, S. (2010). Brownfield development: A comparison of North American and British approaches. Urban Studies, 47(1), 75-104.

Alker, S., Joy, V., Roberts, P \& Smith, N. (2000). The definition of brownfield. Journal of Environmental Planning and Management, 43(1), 49-69.

Andres, L. \& Grésillon, B. (2013). Cultural brownfields in European cities: a new mainstream object for cultural and urban policies. International Journal of Cultural Policy, 19(1), 40-62.

Apsan, H. N. (2002). Environmental Value: A Business View of Environmental Costs and Opportunities. Environmental Quality Management, 11(4), 75-81.

Bond, S., \& Cook, D. (2004). Residents' Perceptions Towards Asbestos Contamination of Land and It's Impact on Residential Property Values. Pacific Rim Property Research Journal, 10(3), 328352.

Bowes, D. R., \& Ihlanfeldt, K. R. (2001). Identifying the impacts of rail transit stations on residential property values. Journal of Urban Economics, 50(1), 1-25.

Brown, L. (2012). World on the edge: how to prevent environmental and economic collapse. Routledge. New York.

Can, A. (1992). Specification and estimation of hedonic housing price models. Regional Science and Urban Economics, 22(3), 453-474.

Chmielová, P., K. Turečková, S. Martinát, J. Nevima \& Škrabal J. (2017). Perception of Influence of the Brownfields on the Value Property: Case Study of Town Orlova, Czech Republic. In: Vision 2020: Sustainable Economic development, Innovation Management, and Global Growth. Madrid: IBIMA, 2569-2578.

Czech Statistical Office (2018). Statistics. [online]. [2018-05-10]. Available from: https://www.czso.cz/csu/czso/statistiky

CzechInvest (2008). Národní strategie regenerace brownfieldi̊ [online]. [2018-06-09]. Available from: http://www.cityinvestczech.cz/data/files/nsb-595.pdf

De Sousa, C. (2000). Brownfield redevelopment versus greenfield development: A private sector perspective on the costs and risks associated with brownfield redevelopment in the Greater Toronto Area. Journal of Environmental Planning and Management, 43(6), 831-853.

De Sousa, C. A. (2003). Turning brownfields into green space in the City of Toronto. Landscape and urban planning, 62(4), 181-198.

Eiser, J. R., Stafford, T., Henneberry, J., \& Catney, P. (2007). Risk perception and trust in the context of urban brownfields. Environmental Hazards, 7(2), 150-156.

Frantal, B., Greer-Wootten, B., Klusacek, P., Krejci, T., Kunc, J., \& Martinat, S. (2015). Exploring spatial patterns of urban brownfields regeneration: The case of Brno, Czech Republic. Cities, 44, 9-18.

Hesse, M. (2004). Land for logistics: locational dynamics, real estate markets and political regulation of regional distribution complexes. Tijdschrift voor Economische en Sociale Geografie, 95(2), $162-173$

Invest More (2018). Brownfieldy. [online]. [2018-05-10]. Available from: http://www.invest$\mathrm{msr} . \mathrm{com} / \mathrm{cz} / \mathrm{component} /$ investor/?ref=type02\&Itemid=133

Jackson, J. (2002). Urban Sprawl. Urbanismus a území rozvoj, 5(6), 21-28.

Jánošíková, P. \& MacGregor Pelikánová, R. (2017). The Heterogenous Diversity of the Real Estate Transfer Tax in the EU, pp. 247-255 IN: Jajuga, K. Orlowski, L.T., Staehr, K. (Eds.). Contemporary Trends and Challenges in Finance. Springer Proceedings in Busienss and Economics, $320 \mathrm{p}$. 
Kaufman, D. A., \& Cloutier, N. R. (2006). The impact of small brownfields and greenspaces on residential property values. The Journal of Real Estate Finance and Economics, 33(1), 19-30.

Kladivo, P. \& M. Halas, (2012). Quality of life in an urban environment: A typology of urban units of Olomouc. Quaestiones Geographicae, 31(2), 49-60.

Krzysztofik, R., Runge, J., \& Kantor-Pietraga, I. (2012). Paths of Environmental and Economic Reclamation: the Case of Post-Mining Brownfields. Polish Journal of Environmental Studies, 21(1), 219-223.

Krzysztofik, R., Tkocz, M., Sporna, T \& Kantor-Pietraga, I. (2016). Some dilemmas of postindustrialism in a region of traditional industry: The case of the Katowice conurbation, Poland. Moravian Geographical Reports, 24(1), 42-54.

Litt, J. S., Tran, N. L., \& Burke, T. A. (2002). Examining urban brownfields through the public health" macroscope". Environmental Health Perspectives, 110(Suppl 2), 183.

Martinát, S. \& Turečková, K. (2016). Local development in the post-mining countryside? Impacts of an agricultural ad plant on rural community. Geographia Technica, 11(1), 54-66. ISSN 20654421.

Martinát, S., Navrátil, J., Pícha, K., Turečková, K. \& Klusáček, P. (2017). Brownfield regeneration from the perspective of residents: place circumstances versus character of respondents. DETUROPE - The Journal of Regional Development and Tourism, 9(2), 71-92.

Melecký, L. \& Staníčková, M. (2017). Cost Efficiency of EU Funded Projects: Case of Selected SMEs in the Moravian-Silesian Region. In: Strategic Management and its Support by Information Systems. Ostrava: VŠB TU Ostrava, 293-302.

Mihaescu, O., \& vom Hofe, R. (2012). The impact of brownfields on residential property values in Cincinnati, Ohio: A spatial hedonic approach. Journal of Regional Analysis \& Policy, 42(3), 223-236.

Morvay, S. (2017). Cultural ambitions of cities in Central and Eastern Europe in the light of two cities - Tallin and Maribor - case studies. DETUROPE - Journal of Regional Development and Tourism, 9(3), 162-176.

Munroe, D. K. (2007). Exploring the determinants of spatial pattern in residential land markets: amenities and disamenities in Charlotte, NC, USA. Environment and Planning B: Planning and Design, 34(2), 336-354.

Navrátil, J., Pícha, K., Martinát, S., NathanaiL, P. C., Turečková, K. \& Holešínská, A. (2018). Resident's preferences for urban brownfield revitalization: Insights from two Czech cities. Land Use Policy, 76(1), 224-234. DOI: 10.1016/j.landusepol.2018.05.013.

OECD (2017). The Governance of Land Use - Policy Highlights [online]. [2018-05-12]. Available from: https://www.oecd.org/cfe/regional-policy/governance-of-land-use-policy-highlights.pdf

Oliver, J. E. (2001). Democracy in Suburbia. Princenton: Princenton Uversity Press.

Pakšiová, R. (2016). Understanding of corporate social responsibility in large companies in Slovakia within the context of a sustainable development. In: Economic policy in the European union member countries: proceedings of 14th international scientific conference. Karviná: OPF in Karviná, SU in Opava, 516-525.

Pediaditi, K., Doick, K. J., \& Moffat, A. J. (2010). Monitoring and evaluation practice for brownfield, regeneration to greenspace initiatives: A meta-evaluation of assessment and monitoring tools. Landscape and Urban Planning, 97(1), 22-36.

Putman, R. (2001). Bowling Alone. The Collapse and Revival of American Community. New York: Simon and Schuster.

Růžičková, E.D. \& MacGregor Pelikánová, R. (2014). Recent trends in the regime of transfer tax in the Czech Republic and selected EU member states. Scientific Papers of the University of Pardubice, Series D 2/2014, 31, 25-33.

Škrabal, J., K. Turečková, S. Martinát, J. Nevima \& Chmielová, P. (2017). Brownfields in context of property, house and real estate price in Dětmarovice (Czech Republic). In: Vision 2020: Sustainable Economic development, Innovation Management, and Global Growth. Madrid: IBIMA, 2720-2728. 
Somlyódyné Pfeil, E. (2017). Chances of Effective Urban Policy in Hungary under the Influence of the European Cohesion Policy. DETUROPE - Journal of Regional Development and Tourism, 9(3), 141-161.

Sucháček, J. (2013). Investment location from the perspective of urban and regional activities in the Czech Republic. In: Culik, M. (ed.): Financial Management of Firms and Financial Institutions: 9th international scientific conference: proceedings. Ostrava: VŠB - TU, 851-857.

Sun, W., \& Jones, B. (2013). Using multi-scale spatial and statistical analysis to assess the effects of brownfield redevelopment on surrounding residential property values in Milwaukee County, USA. Moravian Geographical Reports, 21(2), 56-64.

Sýkora, L. (2003). Suburbanizace a její společenské důsledky. Praha, Sociologický ústav AV ČR.

Tagaia, G. (2016). The territorial dimension of social exclusion in East-Central Europe. DETUROPE - The Journal of Regional Development and Tourism, 8(2), 58-71.

Turečková, K. (2018). The Role of Public Administration and EU in the context of Brownfields. In: Proceedings of the 4rd International Conference on European Integration 2018. Ostrava: VŠBTU Ostrava, 1522-1530.

Turečková, K., Nevima, J., Škrabal, J. \& Martinát, S. (2018). Uncovering patterns of location of brownfields to facilitate their regeneration: Some remarks from the Czech Republic. Sustainability, 10(6), 224-234. DOI: 10.3390/su10061984.

Turečková, K., S. Martinát, J. Nevima, J. Škrabal \& Chmielová, P. (2017b). Impact of brownfields on the real estate prices: A case study from three locations in the Moravian Silesian Region (Czech Republic). In: Vision 2020: Sustainable Economic development, Innovation Management, and Global Growth. Madrid: IBIMA, 2560-2568.

Turečková, K., S. Martinát, J. Škrabal, P. Chmielová \& Nevima, J. (2017a). How local population perceive impact of brownfields on the residential property values: some remarks from postindustrial areas in the Czech Republic. Geographia Technica, 12(2), 150-164.

Yount, K. R. (2003). 'What are brownfields? Finding a conceptual definition. Environmental Practice. 5(01), 25-33. 